\title{
Identification and Validation of a New Male Sex-Specific ISSR Marker in Pointed Gourd (Trichosanthes dioica Roxb.)
}

\author{
Sinchan Adhikari, ${ }^{1}$ Soumen Saha, ${ }^{1}$ Tapas Kumar Bandyopadhyay, ${ }^{2}$ and Parthadeb Ghosh ${ }^{1}$ \\ ${ }^{1}$ Cytogenetics \& Plant Breeding Section, Plant Biotechnology Research Unit, Department of Botany, \\ University of Kalyani, Kalyani, Nadia, West Bengal 741235, India \\ ${ }^{2}$ Department of Molecular Biology \& Biotechnology, University of Kalyani, Kalyani, Nadia, West Bengal 741235, India
}

Correspondence should be addressed to Parthadeb Ghosh; pdgbot@yahoo.co.in

Received 30 July 2014; Accepted 10 October 2014; Published 5 November 2014

Academic Editor: Boris Vyskot

Copyright (C) 2014 Sinchan Adhikari et al. This is an open access article distributed under the Creative Commons Attribution License, which permits unrestricted use, distribution, and reproduction in any medium, provided the original work is properly cited.

\begin{abstract}
The aim of the present study was to develop a genetic sex marker for the pointed gourd (Trichosanthes dioica Roxb.) to allow gender determination at any stage in the life cycle. Screening of genomic DNA with intersimple sequence repeat (ISSR) primers was used to discover sex-specific touch-down polymerase chain reaction (Td-PCR) amplification products. Using pooled DNA from male and female genotypes and 42 ISSR primers, a putative male specific marker ( $550 \mathrm{bp})$ was identified. DNA marker specific to male is an indication of existence of nonepigenetic factors involved in gender development in pointed gourd. The ISSR technique has proved to be a reliable technique in gender determination of pointed gourd genotypes at the seedling phenophase. The sex marker developed here could also be used as a starting material towards sequence characterization of sex linked genes for better understanding the developmental as well as evolutionary pathways in sexual dimorphism.
\end{abstract}

\section{Introduction}

Dioecism accompanied by sex chromosome dimorphism is common in animals but less prevalent in plants. In a minority of dioecious plants, sex determination depends on sex chromosomes, usually an XY system, in which males are heterogametic (XY) and females are homogametic (XX) [13]. There are two types of sex chromosomes [2]: homomorphic sex chromosomes, in which the sex chromosomes are morphologically indistinguishable from autosomes and heteromorphic sex chromosomes, which can be discriminated in cytological analyses. Heteromorphic sex chromosomes have been reported in several families (e.g., Cannabis and Humulus, Cannabinaceae; Silene, Caryophyllaceae; Rumex, Polygonaceae) [2], but our understanding of their evolution and genetics is still relatively poor. The presence of dioecious forms in a number of Cucurbitaceous genera makes it an interesting model family to study sexual dimorphism, but the mechanism of sex determination has been studied in only a few such as Coccinia and Bryonia $[4,5]$.
Pointed gourd (Trichosanthes dioica Roxb.) of the family Cucurbitaceae is a perennial, dioecious crop extensively cultivated in tropical and subtropical regions around the world. In India, it is largely grown as a nutritious vegetable in the northern plains from Uttar Pradesh, West Bengal, Bihar, Orissa, to Assam. Breeding programmes in pointed gourd have several constraints such as poor germination, vegetative means of propagation, and dioecy. The plant strictly maintains the sexual phenotypes of male and female indicating clear genetic difference between both sexes. This clear differentiation of sexual phenotype, combined with its perennial nature, an increasing economic importance of the crop, and recent interest in breeding improved cultivars, makes the species attractive for the study of different aspects of sex determination. A reliable molecular strategy for the early identification of sex in T. dioica has been a priority in breeding programs in order to increase their economic potential and better understanding the developmental as well as evolutionary pathways of dimorphism. 
The use of polymerase chain reaction (PCR)-based molecular markers, useful tools for determining genotypes in plant breeding, has now made it possible to select superior or exclude unwanted individuals at the DNA level. Specific genes or markers underlying interesting traits were mapped and identified via molecular markers and can be used to increase the efficiency and precision by selecting individuals that have the desired genetic traits at an early stage [6]. Several molecular markers such as RAPD, AFLP, and microsatellites have been used for early determination of sex in many agronomically important plants before they enter the reproductive stage [7-13]. Since 1994, a new molecular marker technique developed by Zietkiewicz et al. [14] called intersimple sequence repeat (ISSR) has been available. The technique involves the use of a microsatellite core unit bearing oligonucleotide primers, usually $16-25 \mathrm{bp}$ long, nonanchored or anchored at the $5^{\prime}$ or $3^{\prime}$ end with 1-4 degenerate nucleotides. ISSR can be a rapid and easy technique for identifying gender, because it overcomes many of the technical limitations of RAPD and AFLP due to its high reproducibility and simplicity [15].

The aim of the present study was to develop a genetic sex marker for $T$. dioica to allow gender determination at any stage in its life cycle. The importance of the findings in the early identification of sex as well as the possible implications in the understanding the molecular basis of sex determination in T. dioica is also discussed.

\section{Materials and Methods}

2.1. Site Description. West Bengal $\left(20^{\circ} 31^{\prime}-27^{\circ} 12^{\prime}\right.$ North and $85^{\circ} 50^{\prime}-89^{\circ} 52^{\prime}$ East), a state in the eastern zone of India, is bounded on the north by Sikkim and Bhutan, on the east by Assam and Bangladesh, on the south by the Bay of Bengal and on the west by Orissa, Bihar, and Nepal. West Bengal covers a geographical area of $88,752 \mathrm{sq}$. $\mathrm{km}$, which constitutes about $2.7 \%$ of the total land area of India. The diversified landforms, soils, and temperatures provide a complex topography of West Bengal with five agroclimatic zones: Hill Zone (2.48 lakh ha), Terai Zone (2.149 lakh ha), Old Alluvial Zone (17.537 lakh ha), New Alluvial Zone (15.304 lakh ha), Red and Laterite Zone (24.842 lakh ha), and Coastal and Saline Zone (14.569 lakh ha).

2.2. Plant Materials. Male and female individuals of twenty cultivated accessions of pointed gourd were procured randomly from isolated areas of four different agroclimatic zones of West Bengal, India (Figure 1; Table 1). Immature leaf materials collected from sample of adult pistilate and staminate plants after complete observation of flower types were used for DNA extraction. The leaf materials were stored at $-80^{\circ} \mathrm{C}$ prior to DNA extraction.

2.3. DNA Extraction. Total genomic DNA was isolated separately from $100 \mathrm{mg}$ of leaf tissues from male and female individuals of the twenty accessions each according to our established protocol [16]. Concentration of the all DNA samples was readjusted so that each sample contained $30 \mathrm{ng} / \mu \mathrm{L}$ genomic DNAs after spectrophotometer and agarose gel electrophoresis analyses.

2.4. Bulk Segregant Analysis (BSA). Bulked segregant analysis [17] is a method used for rapidly identifying markers linked to any specific gene or genomic region. Two bulked DNA samples are generated from a segregating population from a single cross. Each pool or bulk contains individuals that are identical for a particular trait or genomic region but arbitrary in all unlinked regions. The two bulks are therefore genetically dissimilar in the selected region but seemingly heterozygous in all other regions [17]. Two bulk DNA samples (male and female) were prepared separately by pooling an equal amount of DNA from male and female individuals of the twenty accessions each and amplified with 42 primers. A DNA marker present in the corresponding male and female bulk and absent in the alternate sex bulk was considered as a potential sex-linked marker. BSA was used to screen each individual of known sex independently to identify the sex specificity of the marker.

2.5. Touch-Down Polymerase Chain Reactions. In the present study a touch-down polymerase chain reaction (Td-PCR) approach was used to amplify pointed gourd DNA samples. A total of 42, both $3^{\prime}$ anchored and unanchored 14-19 mer ISSR primers (Bangalore Genei, Bangalore, India), were screened. Each Td-PCR was performed in volumes of $25 \mu \mathrm{L}$ containing $2.5 \mu \mathrm{L}$ of $10 \mathrm{x}$ assay buffer $(100 \mathrm{mM}$ Tris-Cl; $\mathrm{pH} 8.3,500 \mathrm{mM}$ $\mathrm{KCl}, 15 \mathrm{mM} \mathrm{MgCl} 2$ ), $200 \mu \mathrm{M}$ dNTP mix (Bangalore Genei, Bangalore, India), 10 picomoles of primer, 1.0 unit of Taq DNA polymerase (Bangalore Genei), and $30 \mathrm{ng}$ of template DNA. Touch-down polymerase chain reactions were carried out in a DNA Thermal Cycler (Eppendorf, Hamburg, Germany) with the following amplification profiles: 4 min hold at $94^{\circ} \mathrm{C}$, followed by a 10-cycle pre-PCR consisting of $1 \mathrm{~min}$ at $94^{\circ} \mathrm{C}$ for denaturation, $1 \mathrm{~min}$ at 50 or $45^{\circ} \mathrm{C}$ for annealing, and $1 \mathrm{~min} 15 \mathrm{sec}$ at $72^{\circ} \mathrm{C}$ for extension. The annealing temperature was reduced by $0.5^{\circ} \mathrm{C}$ per cycle for the first 10 cycles (touchdown cycles). Amplification of the targeted DNA templates continued for further 30 cycles at 40 or $45^{\circ} \mathrm{C}$ annealing temperature and ended with a final extension step at $72^{\circ} \mathrm{C}$ for $7 \mathrm{~min}$. After Td-PCR completed, samples were stored at $-20^{\circ} \mathrm{C}$ until agarose gel electrophoresis studies.

2.6. Agarose Gel Electrophoresis. Fifteen microliters of amplified Td-PCR products was mixed with $5 \mu \mathrm{L}$ loading buffer containing $0.25 \%(\mathrm{w} / \mathrm{v})$ bromophenol blue, $0.25 \%$ (w/v) xylene cyanol FF, and 40\% (w/v) sucrose. Samples were loaded into the wells of $2 \%(\mathrm{~m} / \mathrm{v})$ agarose gels. Agarose gels were prepared with 1X TAE buffer containing $40 \mathrm{mM}$ Tris (pH 7.6), $20 \mathrm{mM}$ acetic acid, and $1 \mathrm{mM}$ EDTA. DNA samples were then electrophoresed at $4 \mathrm{~V} / \mathrm{cm}$ at constant current for $8-16 \mathrm{~h}$ in the presence of $1 \mathrm{X}$ TAE buffer. After agarose gel electrophoreses completed DNA samples on the gels were visualized and photographed in Gel Documentation System (Uvitec, UK), all experiments were repeated at least three times with appropriate controls to ensure reproducibility and consistency. 

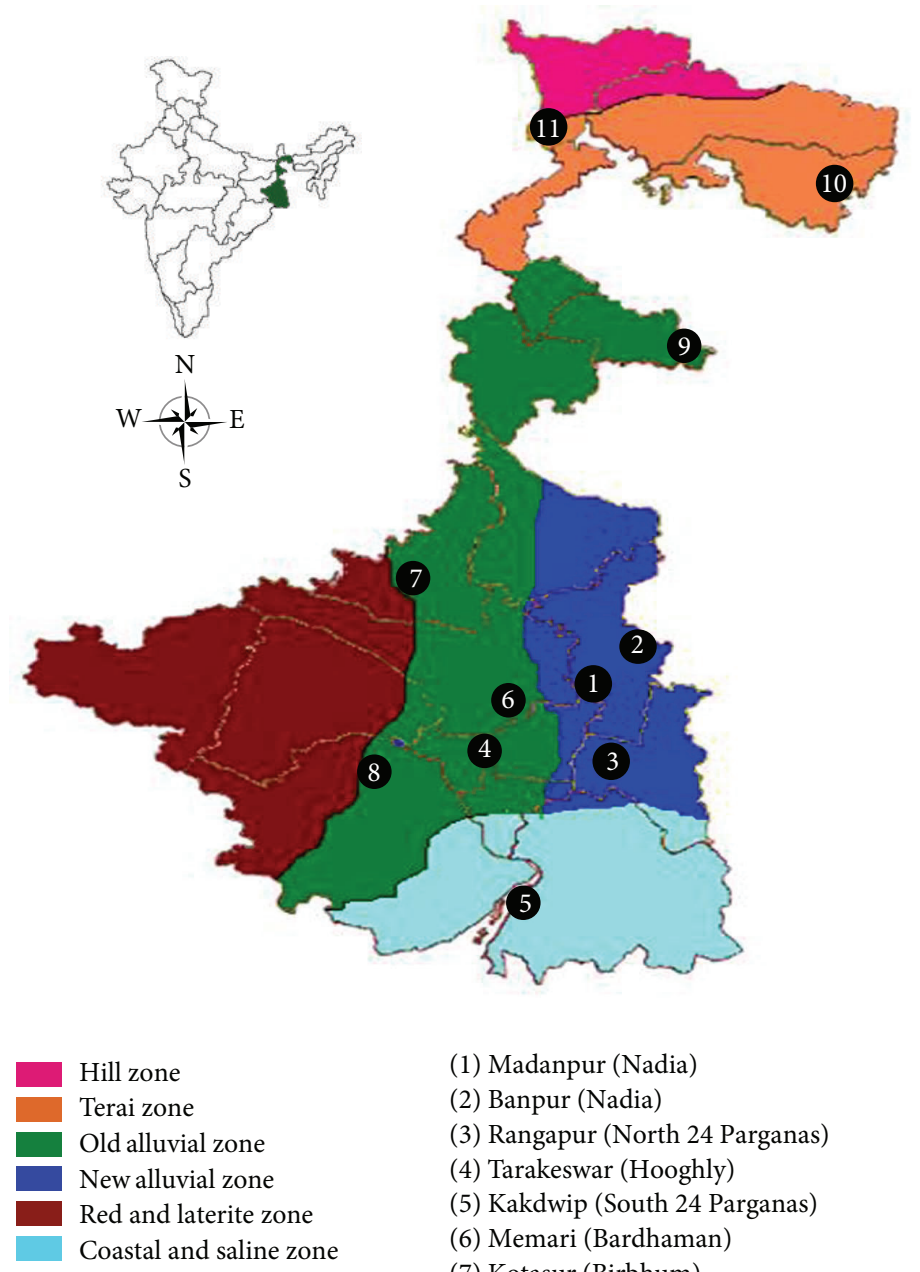
(1) Madanpur (Nadia)
(2) Banpur (Nadia)
(3) Rangapur (North 24 Parganas)
(4) Tarakeswar (Hooghly)
(5) Kakdwip (South 24 Parganas)
(6) Memari (Bardhaman)
(7) Kotasur (Birbhum)
(8) Garbeta (West Midnapore)
(9) Hilli (South Dinajpur)
(10) Pundibari (Cooch Behar)
(11) Kharibari (Darjeeling)

Figure 1: Agroclimatic zones of West Bengal showing localities of collection of pointed gourd accessions. Collection sites are marked with a circle and numbered from 1 to 11 .

\section{Results and Discussion}

Male and female DNA pools of twenty accessions of pointed gourd were screened with 42 ISSR primers for sex-specific polymorphisms and reproducibility. Since lengths, sequence, and annealing temperatures of primers used in the present study were quite different, the value selected for the annealing temperatures and other variables including the concentrations of $\mathrm{Mg}^{2+}$, dNTPs and template were determined empirically. The optimized Td-PCR produced repetitive results within and between PCRs and between templates obtained from each repeat of experiment. Of the 42 ISSR primers used to amplify the bulk DNA from male and female individuals, 21 primers gave a reproducible ISSR pattern (Table 2). Several DNA templates were amplified within the same PCR runs and between different PCR runs. The number of amplification products varied from 1 to 10 , and the fragment sizes ranged from 100 to 2,000 bp. Reproducible results obtained from the Td-PCRs indicated that amplification of the nonspecific sequences was avoided. Of all the 42 primers tested, only one primer, ISSR-6, was found to show sex specificity in bulk analysis. Primer ISSR-6 (5'-GACAGACAGACAGACA$3^{\prime}$ ) produced a unique $\sim 550$ base-pair fragment in male bulk DNA, and this band was absent in female bulk DNA (Figure 2). To confirm this observation, the primer (ISSR-6) showing polymorphism for the sex type was used to retest the DNAs amplification with individual male and female samples from the twenty accessions. Interestingly, the unique $\sim 550$ bp fragment was present in all male individuals of the twenty accessions (Figure 2) and was completely absent in the respective female individuals tested.

Recent studies on sex-determining mechanisms in angiosperms have clearly revealed that a variety of sexdetermining mechanisms have evolved which involve a number of different genetic and epigenetic parameters [18]. The most extreme type of sex determination system is found 
TABLE 1: Pointed gourd accessions collected from different locations of West Bengal, India.

\begin{tabular}{|c|c|c|c|c|c|c|c|}
\hline \multirow{2}{*}{ Accession name } & \multirow{2}{*}{ Collection site } & \multirow{2}{*}{ District } & \multirow{2}{*}{ Latitude } & \multirow{2}{*}{ Longitude } & \multirow{2}{*}{ Altitude (feet) } & \multicolumn{2}{|c|}{ Sex } \\
\hline & & & & & & Male (M) & Female $(\mathrm{F})$ \\
\hline Kajli & Madanpur & Nadia & $23^{\circ} 1^{\prime} 0 \mathrm{~N}$ & $88^{\circ} 28^{\prime} 60 \mathrm{E}$ & 29 & $\mathrm{M}$ & $\mathrm{F}$ \\
\hline Madanpur & Madanpur & Nadia & $23^{\circ} 1^{\prime} 0 \mathrm{~N}$ & $88^{\circ} 28^{\prime} 60 \mathrm{E}$ & 29 & M & $\mathrm{F}$ \\
\hline Banpur & Banpur & Nadia & $23^{\circ} 26^{\prime} 60 \mathrm{~N}$ & $88^{\circ} 46^{\prime} 0 \mathrm{E}$ & 42 & M & $\mathrm{F}$ \\
\hline Haribatkhali & Rangapur & North 24 Parganas & $22^{\circ} 45^{\prime} 41 \mathrm{~N}$ & $88^{\circ} 22^{\prime} 19 \mathrm{E}$ & 49 & M & $\mathrm{F}$ \\
\hline Haludkhali & Rangapur & North 24 Parganas & $22^{\circ} 45^{\prime} 41 \mathrm{~N}$ & $88^{\circ} 22^{\prime} 19 \mathrm{E}$ & 49 & M & $\mathrm{F}$ \\
\hline Pabda & Rangapur & North 24 Parganas & $22^{\circ} 45^{\prime} 41 \mathrm{~N}$ & $88^{\circ} 22^{\prime} 19 \mathrm{E}$ & 49 & M & $\mathrm{F}$ \\
\hline Dhapa & Rangapur & North 24 Parganas & $22^{\circ} 45^{\prime} 41 \mathrm{~N}$ & $88^{\circ} 22^{\prime} 19 \mathrm{E}$ & 49 & M & $\mathrm{F}$ \\
\hline Sada Patol & Rangapur & North 24 Parganas & $22^{\circ} 45^{\prime} 41 \mathrm{~N}$ & $88^{\circ} 22^{\prime} 19 \mathrm{E}$ & 49 & M & $\mathrm{F}$ \\
\hline Kali & Tarakeswar & Hooghly & $22^{\circ} 53^{\prime} 60 \mathrm{~N}$ & $88^{\circ} 1^{\prime} 20 \mathrm{E}$ & 59 & M & $\mathrm{F}$ \\
\hline Sundari & Kakdwip & South 24 Parganas & $21^{\circ} 52^{\prime} 60 \mathrm{~N}$ & $88^{\circ} 10^{\prime} 60 \mathrm{E}$ & 3 & M & $\mathrm{F}$ \\
\hline Sandhyamoni & Kakdwip & South 24 Parganas & $21^{\circ} 52^{\prime} 60 \mathrm{~N}$ & $88^{\circ} 10^{\prime} 60 \mathrm{E}$ & 3 & M & $\mathrm{F}$ \\
\hline Damodar & Memari & Burdwan & $23^{\circ} 11^{\prime} 60 \mathrm{~N}$ & $88^{\circ} 7^{\prime} 0 \mathrm{E}$ & 78 & M & $\mathrm{F}$ \\
\hline Guli & Memari & Burdwan & $23^{\circ} 11^{\prime} 60 \mathrm{~N}$ & $88^{\circ} 7^{\prime} 0 \mathrm{E}$ & 78 & M & $\mathrm{F}$ \\
\hline Ghugut & Memari & Burdwan & $23^{\circ} 11^{\prime} 60 \mathrm{~N}$ & $88^{\circ} 7^{\prime} 0 \mathrm{E}$ & 78 & M & $\mathrm{F}$ \\
\hline Korda & Kotasur & Birbhum & $23^{\circ} 56^{\prime} 60 \mathrm{~N}$ & $87^{\circ} 40^{\prime} 0 \mathrm{E}$ & 173 & M & $\mathrm{F}$ \\
\hline Hijli & Garbeta & West Midnapore & $22^{\circ} 49^{\prime} 60 \mathrm{~N}$ & $87^{\circ} 19^{\prime} 60 \mathrm{E}$ & 177 & M & $\mathrm{F}$ \\
\hline Hilli & Hilli & South Dinajpur & $25^{\circ} 13^{\prime} 0 \mathrm{~N}$ & $88^{\circ} 46^{\prime} 0 \mathrm{E}$ & 82 & M & $\mathrm{F}$ \\
\hline Coochbehar local & Pundibari & Cooch Behar & $26^{\circ} 15^{\prime} 0 \mathrm{~N}$ & $89^{\circ} 30^{\prime} 0 \mathrm{E}$ & 154 & M & $\mathrm{F}$ \\
\hline Kharibari & Kharibari & Darjeeling & $26^{\circ} 21^{\prime} 0 \mathrm{~N}$ & $88^{\circ} 55^{\prime} 0 \mathrm{E}$ & 190 & M & $\mathrm{F}$ \\
\hline
\end{tabular}

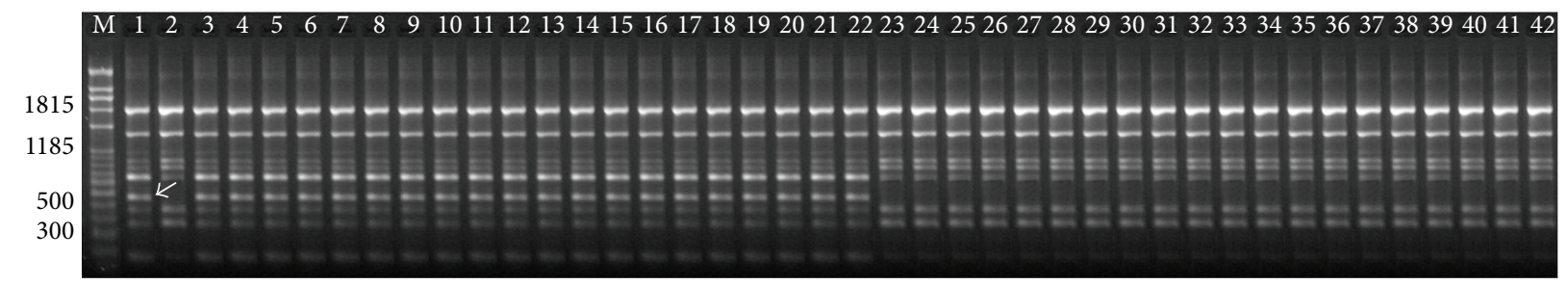

FIGURE 2: ISSR banding patterns of male and female plants of Trichosanthes dioica obtained with the primer ISSR- 6 (5'GACAGACAGACAGACA- $3^{\prime}$ ). The arrow indicates the unique band of $\sim 550$ bp present in the male bulk. lane 1, bulk male; lane 2, bulk female; lanes 3-22, male individuals; lanes 23-42, female individuals; M denotes molecular mass marker (100 bp ladder).

where highly specialized sex chromosomes are found; this type of system usually promotes dioecy in plants [19]. In the absence of genetic information on sex determination in dioecious plant, the use of molecular markers for discriminating between staminate and pistillate genotypes is worthwhile. PCR-based DNA technology has been proved to be a reliable strategy for detection of sex-associated markers in dioecious and bisexual taxa. In general, sex markers have been developed only rarely for plants with presumably autosomal sex determination, including Atriplex garrettii [20], Salix viminalis [21, 22], and Uapaca kirkiana [23]. It is clearly more likely to find sex-linked markers in cases where a sex chromosome system operates. Also, most of the known sex-linked markers are male associated, which reflects males being the heterogametic sex [1].

In earlier studies, three different molecular markers associated with sex expression in pointed gourd were screened using randomly amplified polymorphic DNA (RAPD) technique $[24,25]$. However, they are not found to be reliable enough for detecting sex of pointed gourd genotypes from different geographical regions. Transcript profiling of unopened male and female floral buds of $T$. dioica has also been used in order to look for the differentially expressed unique and/or upregulated gene fragments associated with the sex expression; however, most of the fragments could not be annotated with any protein function reported till date [26]. Recently, sex-linked STS marker derived from ISSR fragment was developed for sex detection of $T$. dioica reflecting no significant homology with any structural gene sequences and did not carry any true open reading frame, probably indicating the paucity of information in this field [27].

Simple sequence repeats (SSRs) are abundantly present in the eukaryotic genomes making the amplification of delimited fragments with ISSR primers quick and easy. Moreover, ISSR markers lie in their linkage to SSR loci and are known to be linked to coding regions, so that ISSRs are likely to mark gene rich regions [28]. In the present study di, tri and tetra nucleotide SSR motifs GA, AG, GT, CA, AC CT, TG, CAC, GAG, CAA, CTC, GAA, and GACA were used. Out of these AG and GA motifs produced maximum 
TABLE 2: Reproducible ISSR primers, their sequences, and total number of amplified loci.

\begin{tabular}{lcc}
\hline Primer code & Primer sequence $\left(5^{\prime}-3^{\prime}\right)$ & Number of amplified loci \\
\hline ISSR-1 & $(\mathrm{TG})_{8} \mathrm{AT}$ & 3 \\
ISSR-2 & $(\mathrm{GA})_{8} \mathrm{C}$ & 5 \\
ISSR-3 & $(\mathrm{GAA})_{5} \mathrm{GA}$ & 6 \\
ISSR-4 & $(\mathrm{GA})_{6} \mathrm{CC}$ & 8 \\
ISSR-5 & $(\mathrm{CTC})_{4} \mathrm{TC}$ & 6 \\
ISSR-6 & $(\mathrm{GACA})_{4}$ & 10 \\
ISSR-7 & $(\mathrm{CA})_{8} \mathrm{GT}$ & 3 \\
ISSR-8 & $(\mathrm{CT})_{8} \mathrm{GAC}$ & 1 \\
ISSR-9 & $(\mathrm{CA})_{6} \mathrm{AC}$ & 4 \\
ISSR-10 & $(\mathrm{CT})_{8} \mathrm{AC}$ & 2 \\
ISSR-11 & $(\mathrm{CA})_{8} \mathrm{~A}$ & 3 \\
ISSR-12 & $(\mathrm{CAA})_{5}$ & 3 \\
ISSR-13 & $(\mathrm{AG})_{8} \mathrm{~A}$ & 5 \\
ISSR-14 & $(\mathrm{CA})_{7} \mathrm{G}$ & 3 \\
ISSR-15 & $(\mathrm{GAG})_{4} \mathrm{CA}$ & 6 \\
ISSR-16 & $(\mathrm{AC})_{9}$ & 5 \\
ISSR-17 & $(\mathrm{CAC})_{6}$ & 3 \\
ISSR-18 & $(\mathrm{GT})_{8} \mathrm{CA}$ & 2 \\
ISSR-19 & $(\mathrm{AG})_{7} \mathrm{C}$ & 5 \\
ISSR-20 & $(\mathrm{GA})_{8} \mathrm{~A}$ & 6 \\
ISSR-21 & $(\mathrm{AC})_{8} \mathrm{~T}$ & 4 \\
\hline & &
\end{tabular}

scorable loci thus revealing more coverage of the genome, whereas $(\mathrm{GACA})_{4}$, a nonanchored primer, developed a male linked marker. Amplification in the presence of nonanchored primers has also been called microsatellite-primed PCR or MP-PCR [29]. Such amplification does not require genome sequence information and leads to multilocus and highly polymorphous patterns [30].

The tetrameric GACA simple DNA sequence has received attention due to speculations on their relevance for sex determination in the heterogametic sex [31,32]. This marker has been successfully applied in guppy fish [33] and mice [34]; however, scanty reports are available in plants. Gangopadhyay et al. [35] developed a female and hermaphrodite specific sex marker in papaya using $(\mathrm{GACA})_{4}$. Sexual dimorphism was also revealed in betelvine using the tetrameric GACA sequence indicating the linkage of GACA repeat sequence with sex determining loci [36]. In contrary there are some instances where tetrameric GACA repeat (both anchored and nonanchored) was found to be unsuccessful in characterization of gender [37, 38].

\section{Conclusions}

Male linked ISSR- $6_{550}$ marker is found to be reliable enough for detecting sex of pointed gourd genotypes from different geographical regions. This will facilitate screening of plants at the seedling stage and maintain an optimum sex ratio in plantations, as well as save time and costs in ongoing pointed gourd breeding programs. Moreover, sexual dimorphism is reported to be linked to many economically important traits such as disease resistance, leaf quality, and so forth. Exploring the relationship between sex-linked markers and desirable traits (especially to disease resistance, as pointed gourd is affected by many pathogens) in future will assist targeted genetic improvement. Further investigations are underway to sequence the male-specific gene fragment and then to compare it with other similar sequences in order to provide theoretical insights into the mechanism of sex differentiation in pointed gourd.

\section{Conflict of Interests}

The authors declare that there is no conflict of interests regarding the publication of this paper.

\section{Acknowledgments}

The authors would like to thank the University Grants Commission (UGC), New Delhi, India, for financial support. S. Saha wish to acknowledge UGC support for the award of Postdoctoral Fellowship. The authors are also thankful to DST-PURSE and University of Kalyani for providing Central instrumentation facilities for this research project.

\section{References}

[1] C. Ainsworth, "Boys and girls come out to play: the molecular biology of dioecious plants," Annals of Botany, vol. 86, no. 2, pp. 211-221, 2000.

[2] S. Matsunaga and S. Kawano, "Sex determination by sex chromosomes in dioecious plants," Plant Biology, vol. 3, no. 5, pp. 481-488, 2001.

[3] D. Charlesworth, "Plant sex determination and sex chromosomes," Heredity, vol. 88, no. 2, pp. 94-101, 2002.

[4] R. P. Roy and P. M. Roy, "Mechanism of sex determination in Coccinia indica," Journal of the Indian Botanical Society, vol. 50, pp. 391-400, 1971.

[5] C. Correns, "Weitere Beiträge zur Kenntnis der dominierenden Merkmale und der Mosaikbildung der Bastarde," Berichte der Deutschen Botanischen Gesellschaft, vol. 21, no. 3, pp. 195-201, 1903.

[6] B. C. Y. Collard and D. J. Mackill, "Marker-assisted selection: an approach for precision plant breeding in the twenty-first century," Philosophical Transactions of the Royal Society B: Biological Sciences, vol. 363, no. 1491, pp. 557-572, 2008.

[7] A. S. Parasnis, W. Ramakrishna, K. V. Chowdari, V. S. Gupta, and P. K. Ranjekar, "Microsatellite (GATA)(n) reveals sexspecific differences in papaya," Theoretical and Applied Genetics, vol. 99, no. 6, pp. 1047-1052, 1999.

[8] H. Flachowsky, E. Schumann, W. E. Weber, and A. Peil, "Application of AFLP for the detection of sex-specific markers in hemp," Plant Breeding, vol. 120, no. 4, pp. 305-309, 2001.

[9] W.-J. Xu, B.-W. Wang, and K.-M. Cui, "RAPD and SCAR markers linked to sex determination in Eucommia ulmoides Oliv," Euphytica, vol. 136, no. 3, pp. 233-238, 2004.

[10] S. Prakash and J. van Staden, "Sex identification in Encephalartos natalensis (Dyer and Verdoorn) using RAPD markers," Euphytica, vol. 152, no. 2, pp. 197-200, 2006.

[11] J. Jakse, N. Stajner, P. Kozjak, A. Cerenak, and B. Javornik, "Trinucleotide microsatellite repeat is tightly linked to male sex 
in hop (Humulus lupulus L.)," Molecular Breeding, vol. 21, no. 2, pp. 139-148, 2008.

[12] S. Samantaray, K. A. Geetha, K. P. Hidayath, and S. Maiti, "Identification of RAPD markers linked to sex determination in guggal [Commiphora wightii (Arnott.)] Bhandari," Plant Biotechnology Reports, vol. 4, no. 1, pp. 95-99, 2010.

[13] J. R. Al-Obaidi, B. K. Suliman, and N. K. Al-Ani, "Molecularbased marker for sex differentiation of jojoba in vivo and in vitro Iraqi cultivars using RAPD-PCR technique," Scientific Research and Essays, vol. 7, no. 4, pp. 522-527, 2012.

[14] E. Zietkiewicz, A. Rafalski, and D. Labuda, "Genome fingerprinting by simple sequence repeat (SSR)-anchored polymerase chain reaction amplification," Genomics, vol. 20, no. 2, pp. 176183, 1994.

[15] L. Goulão and C. M. Oliveira, "Molecular characterisation of cultivars of apple (Malus $x$ domestica Borkh.) using microsatellite (SSR and ISSR) markers," Euphytica, vol. 122, no. 1, pp. 81-89, 2001.

[16] S. Adhikari, S. K. Chattopadhyay, and P. D. Ghosh, "A simplified high yielding miniprep genomic DNA extraction protocol for three chemotypically different plant species," Indian Journal of Biotechnology, vol. 11, no. 3, pp. 337-340, 2012.

[17] R. W. Mlchelmore, I. Paran, and R. V. Kesseli, "Identification of markers linked to disease-resistance genes by bulked segregant analysis: a rapid method to detect markers in specific genomic regions by using segregating populations," Proceedings of the National Academy of Sciences of the United States of America, vol. 88, no. 21, pp. 9828-9832, 1991.

[18] B. Vyskot and R. Hobza, "Gender in plants: sex chromosomes are emerging from the fog," Trends in Genetics, vol. 20, no. 9, pp. 432-438, 2004.

[19] R. Ming and P. H. Moore, "Genomics of sex chromosomes," Current Opinion in Plant Biology, vol. 10, no. 2, pp. 123-130, 2007.

[20] C. F. Ruas, D. J. Fairbanks, R. P. Evans, H. C. Stutz, W. R. Andersen, and P. M. Ruas, "Male-specific DNA in the dioecious species Atriplex garrettii (Chenopodiaceae)," The American Journal of Botany, vol. 85, no. 2, pp. 162-167, 1998.

[21] C. Alstrom-Rapaport, M. Lascoux, Y. C. Wang, G. Roberts, and G. A. Tuskan, "Identification of a RAPD marker linked to sex determination in the basket willow (Salix viminalis L.)," Journal of Heredity, vol. 89, no. 1, pp. 44-49, 1998.

[22] L. E. Gunter, G. T. Roberts, K. Lee, F. W. Larimer, and G. A. Tuskan, "The development of two flanking SCAR markers linked to a sex determination locus in Salix viminalis L.," Journal of Heredity, vol. 94, no. 2, pp. 185-189, 2003.

[23] W. F. Mwase, S. Erik-Lid, Å. Bjørnstad, B. Stedje, M. B. Kwapata, and J. M. Bokosi, "Application of amplified fragment length polymorphism (AFLPs) for detection of sex-specific markers in dioecious Uapaca kirkiana Muell. Årg," African Journal of Biotechnology, vol. 6, no. 2, pp. 137-142, 2007.

[24] M. Singh, S. Kumar, A. K. Singh, D. Ram, and G. Kalloo, "Female sex-associated RAPD marker in pointed gourd (Trichosanthes dioica Roxb.)," Current Science, vol. 82, no. 2, pp. 131132, 2002.

[25] S. Kumar, B. D. Singh, and D. P. Sinha, "RAPD markers for identification of sex in pointed gourd (Trichosanthes dioica Roxb.)," Indian Journal of Biotechnology, vol. 11, no. 3, pp. 251256, 2012.

[26] S. K. Roy, G. Gangopadhyay, K. Ghose, S. Dey, D. Basu, and K. K. Mukherjee, "A cDNA-AFLP approach to look for differentially expressed gene fragments in dioecious pointed gourd
(Trichosanthes dioica Roxb.) for understanding sex expression," Current Science, vol. 94, no. 3, pp. 381-385, 2008.

[27] S. Nanda, B. Kar, S. Nayak, S. Jha, and R. K. Joshi, "Development of an ISSR based STS marker for sex identification in pointed gourd (Trichosanthes dioica Roxb.)," Scientia Horticulturae, vol. 150, pp. 11-15, 2013.

[28] T. Kojima, T. Nagaoka, K. Noda, and Y. Ogihara, "Genetic linkage map of ISSR and RAPD markers in einkorn wheat in relation to that of RFLP markers," Theoretical and Applied Genetics, vol. 96, no. 1, pp. 37-45, 1998.

[29] W. Meyer, T. G. Mitchell, E. Z. Freedman, and R. Vilgalys, "Hybridization probes for conventional DNA fingerprinting used as single primers in the polymerase chain reaction to distinguish strains of Cryptococcus neoformans," Journal of Clinical Microbiology, vol. 31, no. 9, pp. 2274-2280, 1993.

[30] B. Bornet and M. Branchard, "Nonanchored inter simple sequence repeat (ISSR) markers: reproducible and specific tools for genome Fingerprinting," Plant Molecular Biology Reporter, vol. 19, no. 3, pp. 209-215, 2001.

[31] L. Singh, I. F. Purdom, and K. W. Jones, "Conserved sexchromosome-associated nucleotide sequences in eukaryotes," Cold Spring Harbor Symposia on Quantitative Biology, vol. 45, pp. 805-814, 1981.

[32] H. S. Chandra, "Sex determination: a hypothesis based on noncoding DNA," Proceedings of the National Academy of Sciences of the United States of America, vol. 82, no. 4, pp. 11651169, 1985.

[33] I. Nanda, M. Schartl, W. Feichtinger, J. T. Epplen, and M. Schmid, "Early stages of sex chromosome differentiation in fish as analysed by simple repetitive DNA sequences," Chromosoma, vol. 101, no. 5-6, pp. 301-310, 1992.

[34] R. Schäfer, E. Böltz, A. Becker, F. Bartels, and J. T. Epplen, "The expression of the evolutionarily conserved GATA/GACA repeats in mouse tissues," Chromosoma, vol. 93, no. 6, pp. 496501, 1986.

[35] G. Gangopadhyay, S. K. Roy, K. Ghose et al., "Sex detection of Carica papaya and Cycas circinalis in pre-flowering stage by ISSR and RAPD," Current Science, vol. 92, no. 4, pp. 524-526, 2007.

[36] G. N. Khadke, K. Hima Bindu, and K. V. Ravishankar, "Development of SCAR marker for sex determination in dioecious betelvine (Piper betle L.)," Current Science, vol. 103, no. 6, pp. 712-716, 2012.

[37] P. Sarmah and R. N. Sarma, "Identification of a DNA marker linked to sex determination in Calamus tenuis Roxb., an economically important rattan species in northeast India," Molecular Breeding, vol. 27, no. 1, pp. 115-118, 2011.

[38] O. S. Aleksandrov, M. G. Divashuk, and G. I. Karlov, "Development of a sex-specific molecular marker for Japanese hop Humulus Japonicus Siebold \& Zucc," Russian Journal of Genetics, vol. 47, no. 8, pp. 1145-1149, 2011. 

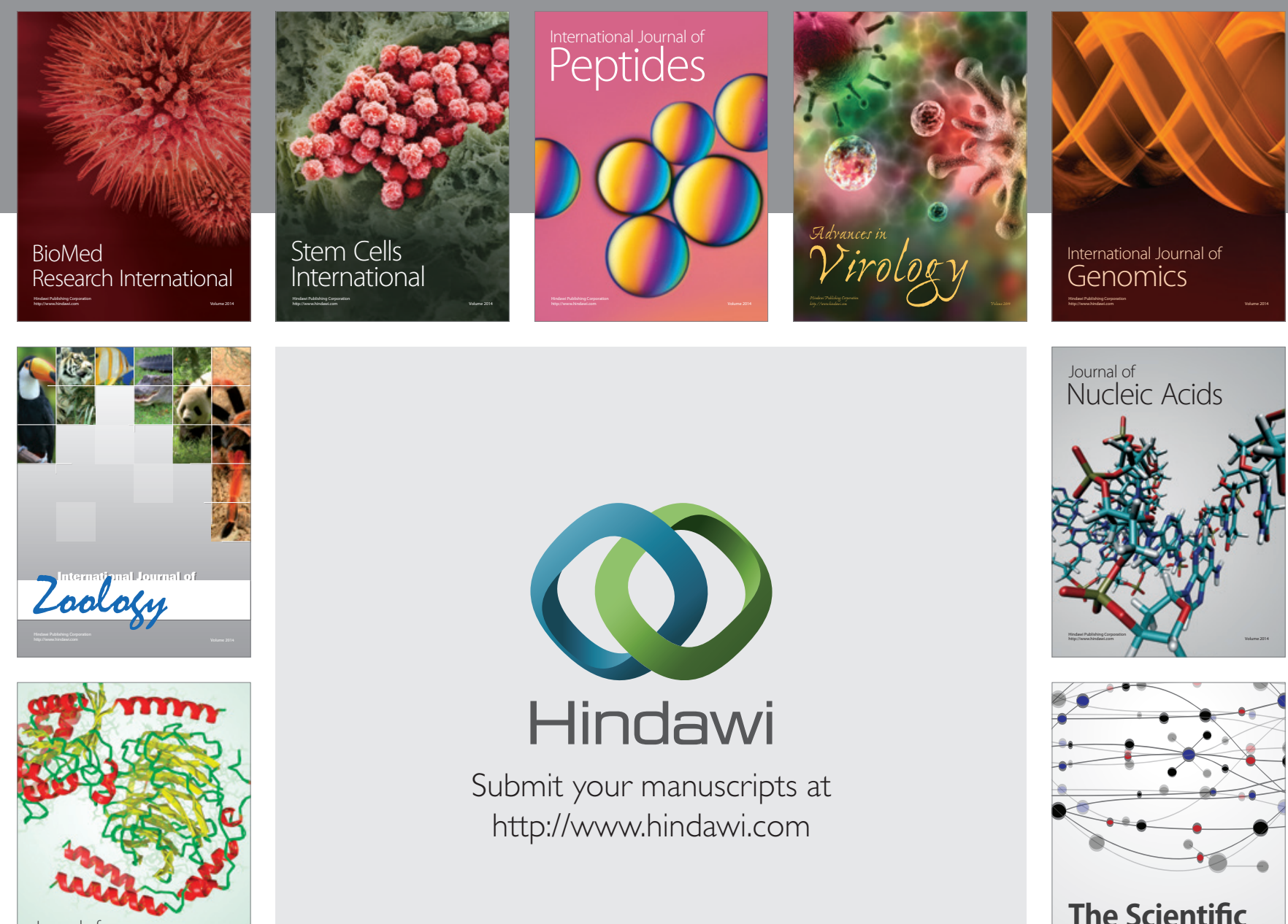

Submit your manuscripts at

http://www.hindawi.com

Journal of
Signal Transduction
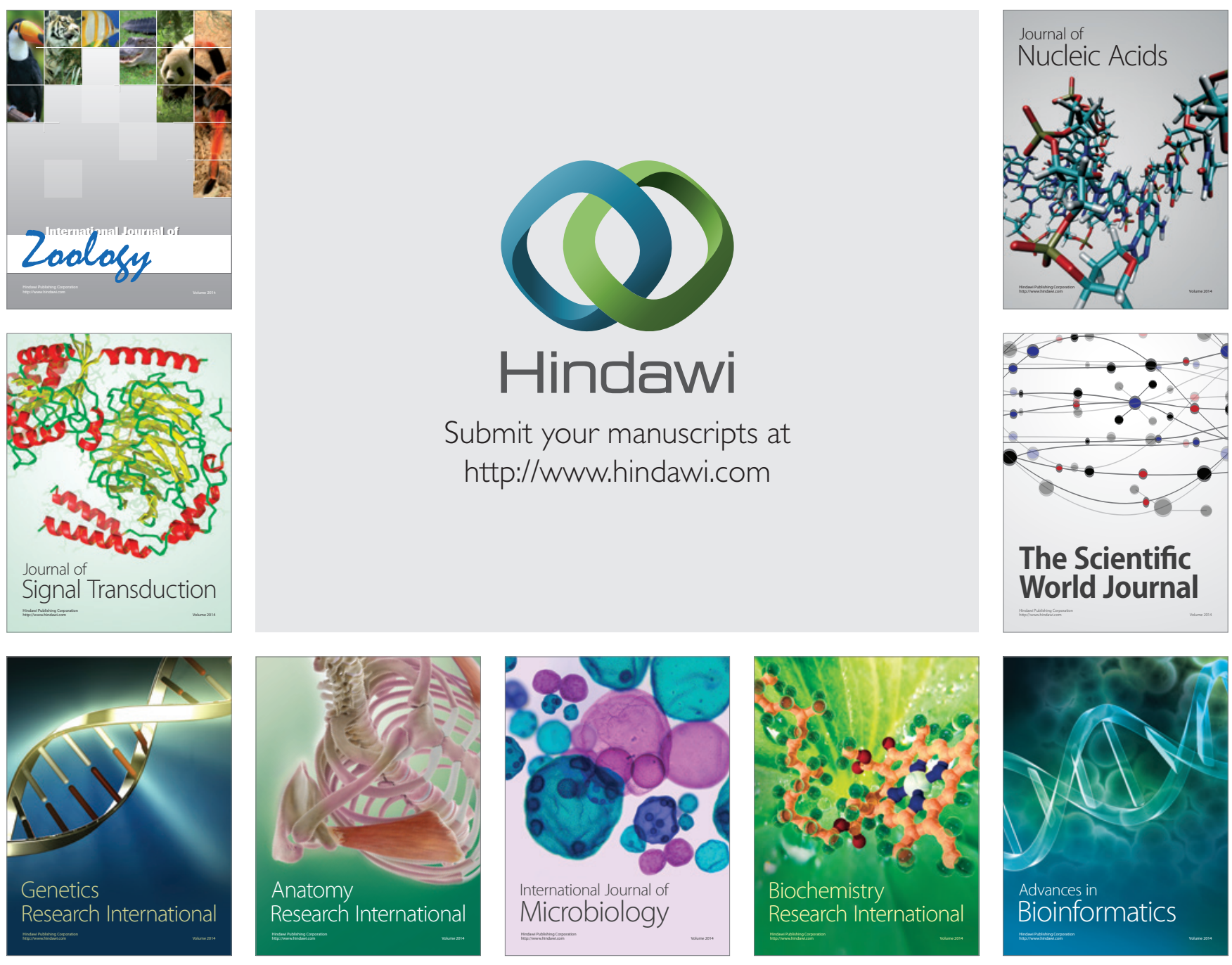

The Scientific World Journal
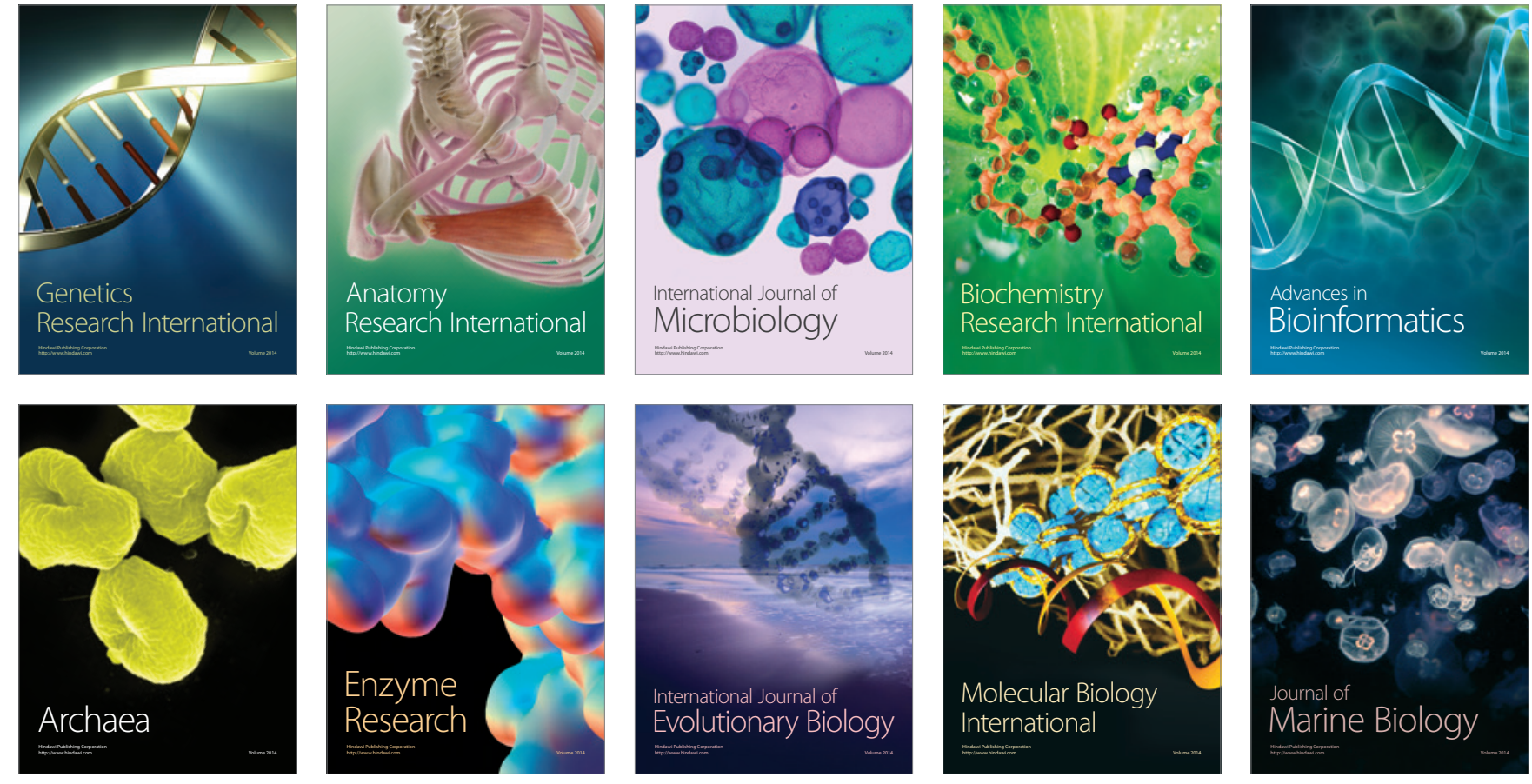